\title{
Systematic Study of Some Recent Pelecypods From Hajam Island in Khor Al- Zubair, Southern Iraq
}

\author{
Ramzi K. Al-Naser \\ Department of Geology \\ Mosul University
}

\author{
Ali H. Elewi \\ Remot Sensing Center \\ Mosul University
}

\section{Mohammed W. Al-Abbasi \\ Dams and water Resources \\ Research Center \\ Mosul University}

(Received 2/6/2008, Accepted 8/10/2008)

\begin{abstract}
Khor Al-Zubair is a shallow arm, semi restricted channel, located at the northwestern part of the Arabian Gulf. The study area ( Hajam island ) is situated at the southern part of the channel, comprised sandy, silty and muddy sediments.

Systematic description is made for the studied pelecypod shells assemblage, which are collected from the Hajam island in Khore Al-Zubair. These assemblage include nine species belonging to seven genera and six families. These species are; Barbatia helblingii, Pinctada margaritifera, Pinctada radiate, Spondylus (Spondylus) gaederopus, Diplodonta (Diplodonta) rotundata, Semele sinensis, Circe (Circe) scripta, Circe (Circe) intermedia and Bassina (Bassina) calophylla.

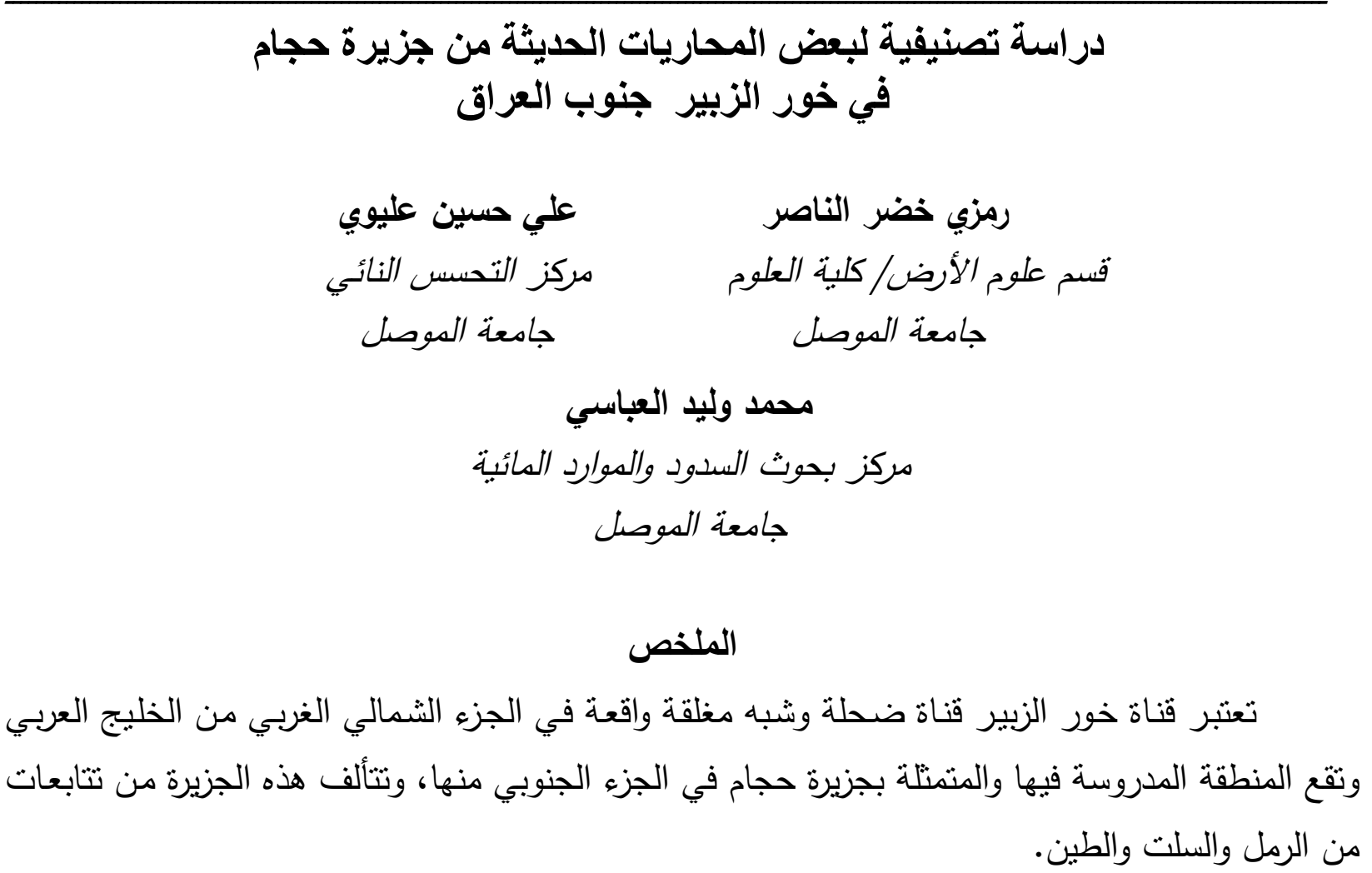


تم خلال هذا البحث وصف وتصنيف عدد من أصداف المحاريات الحديثة والتي تمثلت بتسعة أنواع

$$
\text { تابعة لسبعة أجناس وستة عوائل وهذه الأنواع هي: }
$$

Barbatia helblingii, Pinctada margaritifera, Pinctada radiate, Spondylus (Spondylus) gaederopus, Diplodonta (Diplodonta) rotundata, Semele sinensis, Circe (Circe) scripta, Circe (Circe) intermedia and Bassina (Bassina) calophylla.

\section{INTRODUCTION}

Khor Al-Zubair is a shallow arm branching of the Arabian Gulf, represents a semiclosed, land locked environments (Elewi and Safawee, 1987). Its extended for about (40) $\mathrm{km}$ long and (1.0 to 1.5$) \mathrm{km}$ wide, located between ( $30^{\circ}$ and $30^{\circ} 20^{\prime} \mathrm{N}$ latitude) and between ( $47^{\circ} 50^{\prime}$ and $48^{\circ}$ E longitude). Its connection with the Arabian Gulf at its northwestern part with constricted mouth like shape ( Fig. 1). The main aim of the present study to illustrate the systematic description of some recent pelecypod organisms, which were mainly occur as articulated and well preserved two valves.

The studied pelecupod shells with the other associated organisms such as; Gastropoda, Ostracoda and benthonic foraminifera, were randomly distributed in sandy and muddy facies within the circumference of the Hajam island, from where the organism shells were collected, these collection indicate a shallow marine environment with low salinity value as men tioned by Vrsaljlo et al., 2006.

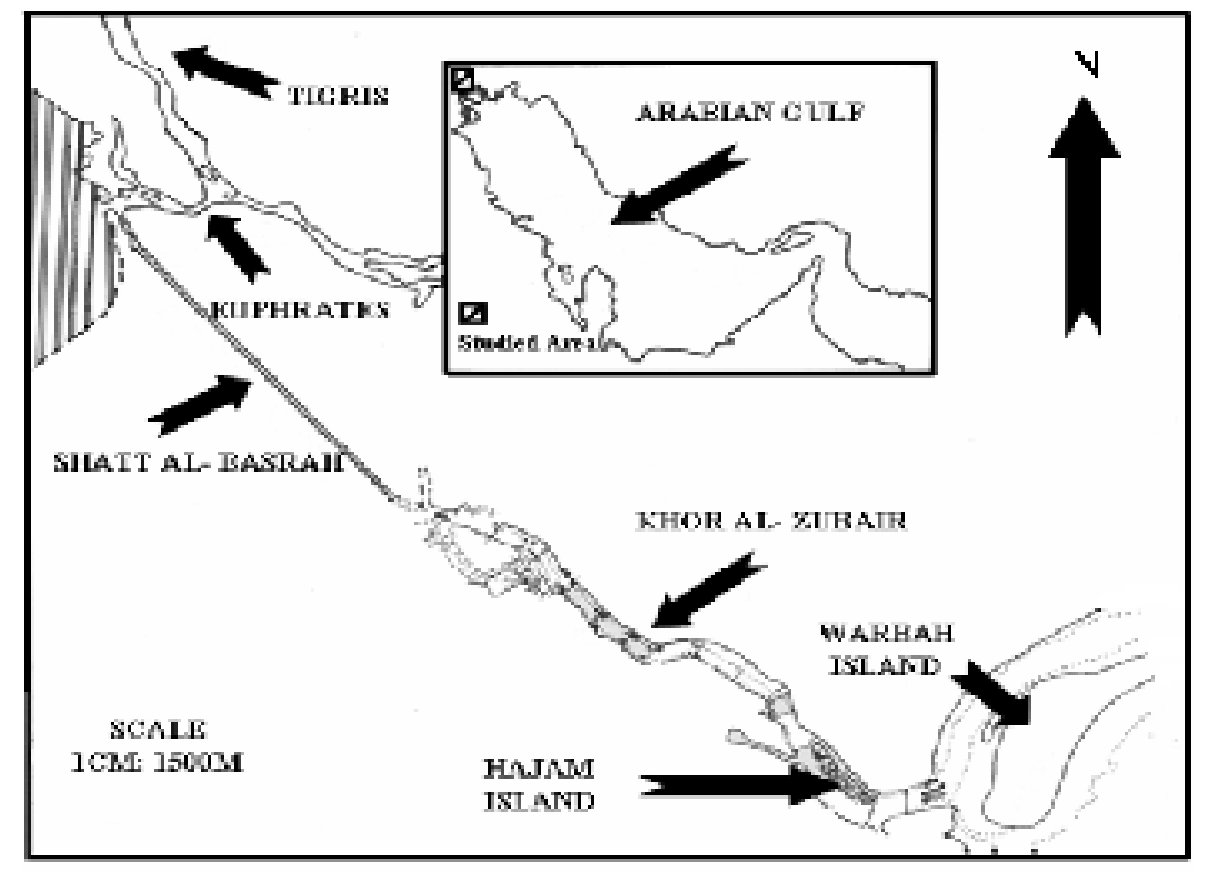

Fig. 1: Location map (modified from Elewi and Safawee, 1989).

\section{SYSTEMATIC DESCRIPTION}

The specimens were identified and fully described depending on their external and internal shell features, using (Cox et al., 1969), (Cox et al., 1969a), (Stenzel, 1971), ( Campbell, 1982) and (Mondadori, 1982). 
Nine species belonging to seven genera and six families were identified in this study. The measured shell parameters (shell height and shell length) were showen on the sketch diagram ( Fig.2).

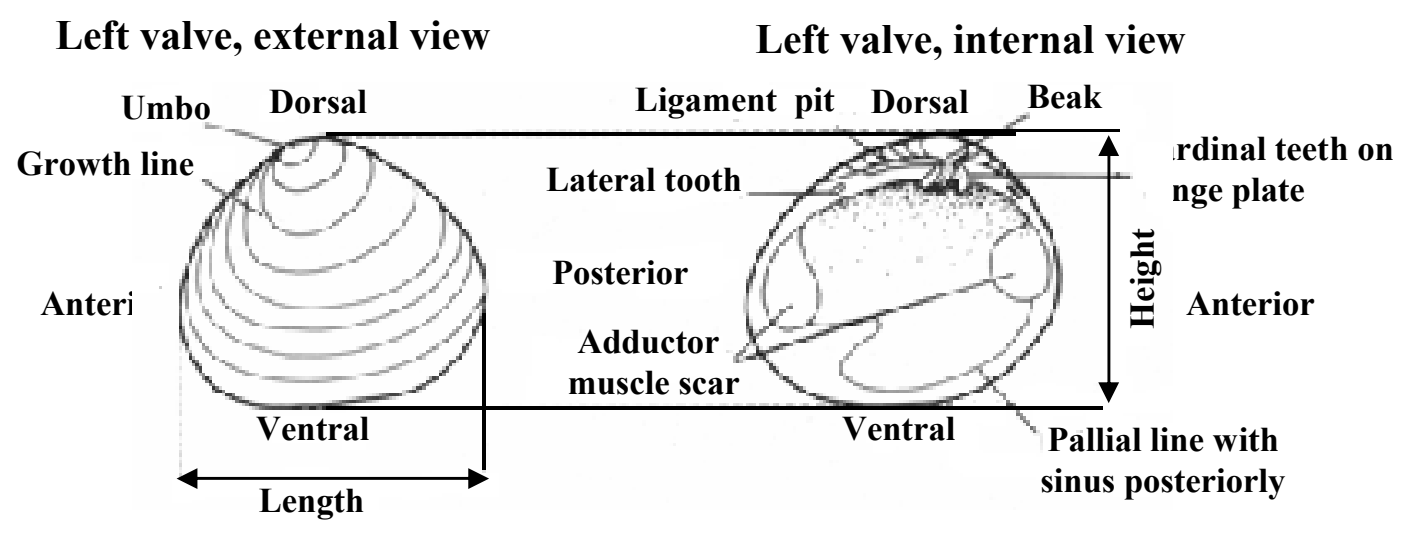

Fig. 2: sketch diagram showing the measured pelecypod shell parameters; height and length means ( $\mathrm{H}$ and $\mathbf{L}$ ) recpectively.

\title{
DEPOSITARY
}

All the specimens were deposited in the Mosul University, Department of Geology, lab. number (201), under the specimens numbers (HJ.1 - HJ.37).

\author{
Phylum: MOLLUSCA \\ Class: BIVALVIA LINNE, 1758 \\ Subclass: PTERIOMORPHIA BEURLEN, 1944 \\ Order: ARCOIDA STOLICZA, 1871 \\ Super family: ARCACEA LAMARCK, 1809 \\ Family: ARCIDAE LAMARCK, 1809 \\ Subfamily: ARCINAE LAMARCK, 1809 \\ Genus: Barbatia GRAY, 184
}

Type species: Arca barbatia LINNE, 1758, SD by GRAY

Barbatia helblingii (BRUGIERE, 1789)

(Plate 2, Fig. 3a, 3b)

SYNONYMY:

1789 Arca helblingii BRUGIERE, P. 99

Dimensions:

\begin{tabular}{|c|c|c|}
\hline $\begin{array}{c}\text { Specimen } \\
\text { numberes(n) }\end{array}$ & height & length \\
\hline 1 & 0.9 & 1.5 \\
\hline 2 & 0.7 & 1.4 \\
\hline 3 & 1.0 & 1.7 \\
\hline 4 & 1.0 & 1.6 \\
\hline 5 & 0.8 & 1.2 \\
\hline 6 & 0.9 & 1.3 \\
\hline
\end{tabular}




\section{Description:}

Small sized shell averaging about $56 \%$ as height as length $(\mathrm{H}=0.9 \mathrm{~cm}, \mathrm{~L}=1.6 \mathrm{~cm}$, $\mathrm{n}=6$ ), subtrapezoidal to subquadrate, semiequivalent conjugated valves, the left valve slightly larger than the right valve. Dorsal shell margin almost straight, posterior and anterior margins are mostly subparallel, curved towards the ventral margin, which is oftenly straight with a sulcation in the middle. Umbo moderately raised, curved towards the anterior margin. Cardinal area straight, teeth are heterodonta to taxodonta, numerous radial coarse ribs radiating from the umbo towards the anterior shell margin, growth lines are mostly faint and concentric making a reticulate type of ornaments with the ribs.

\section{Remarks:}

Barbatia helblingii BRUGIERE, 1789 is slightly differs from Barbatia lacerate BRUGIERE, 1789 in having a higher and widen ligament area.

Order: PTERIOIDA NEWELL, 1965

Suborder: PTERIINA NEWELL, 1965

Super family: PTERIACEA GRAY, 1847

Family: PTERIACEA GRAY, 1847

Genus: Pinctada RODING, 1798

Type species: Mytilus margaritiferus LINNE, 1758,P.704,SD IREDALE 1915,P.30

Pinctada margaritifera (LINNE, 1758)

(Plate 2, Fig. 5a)

SYNONYMY:

1758 Mytilus margaritifera LINNE, P.704

1869 Meleagrina margaritifera ISSEL, P.95

1907 Margaritifera Margaritifera MELVILL and STANDEN P.803

Dimensions:

\begin{tabular}{|c|c|c|}
\hline $\begin{array}{c}\text { Specimen } \\
\text { numberes(n) }\end{array}$ & height & length \\
\hline 1 & 5.1 & 5.0 \\
\hline 2 & 5.0 & 4.9 \\
\hline 3 & 5.3 & 5.1 \\
\hline 4 & 5.2 & 5.0 \\
\hline
\end{tabular}

\section{Description:}

Medium sized shell, averaging about $96 \%$ as length as height $(\mathrm{H}=5.2 \mathrm{Cm}, \mathrm{L}=5.0$ $\mathrm{cm}, \mathrm{n}=4$ ), subquadrate, inequivalent valves with the convex left valve is slightly larger than the concave right valve. umbo Prosogyral (peak directed forward), anterior margin straight, posterior margin almost inclined, both margins attached with the dorsal straight margin, making a subtriangular alates, then towards the ventral margin. The external shell surface is well ornamented by numerous concentric growth lines, arranged themself like crenulated an overlap laminae, radial ribs radiated from the umbo towards the ventral margin. Shell outline is mostly plicated. hingement attached only by ligament (no hinge teeth), monomyrian adductor muscle scar, particularly occur at the posterior shell margin and become occasionally central in position. 


\section{Remarks:}

It differs from the genus Pteria, with the type species $P$. hurunda (LINNE) in (Cox et al., 1969, P.303, Fig. C38,4) which shows in its distinguishable elongated posterior wing.

Pinctada radiata LEACH, 1814 (Plate1, Fig. 4a, 4b)

SYNONYMY:

1814 Pinctada radiata LEACH, P.98, PL.43

1817 Perlamater vulgaris SCHUMACHER, P108

1939 Pteria (Pinctada) vulgaris MOAZOO, P.42, PL.4, Fig.1.

1973 Pinctada radiate LEACH in BIGGS, P.384

Dimensions:

\begin{tabular}{|c|c|c|}
\hline $\begin{array}{c}\text { Specimen } \\
\text { numberes(n) }\end{array}$ & height & length \\
\hline 1 & 4.9 & 4.7 \\
\hline 2 & 5.1 & 4.9 \\
\hline 3 & 5.0 & 4.8 \\
\hline 4 & 4.7 & 4.5 \\
\hline
\end{tabular}

\section{Description:}

Medium sized shell averaging about $96 \%$ as length as height $(\mathrm{H}=4.9 \mathrm{Cm}, \mathrm{L}=4.7$ $\mathrm{cm}, \mathrm{n}=4$ ), semiequivalent to subquadrate conjugated valves. Left valve is almost plane to slightly concave, right valve moderately convex, Dorsal margin straight, umbo Prosogyral, slightly projecting upward, occur at $1 / 3$ of the anterior margin. Posterior and anterior margins are strongly concave towards at about $1 / 4$ from the dorsal margin making subtriangular to a triangulate alates (ears), becoming subparallel and then curved towards the circular ventral margin. External shell surface are well ornamented by numerous growth lines and faint concentric fila crossed by moderately plicated radial ribs, radiating from the umbo towards the crenulated ventro- lateral shell outlines. Internal shell features are composed of a strong ligament (disodont teeth) and by a pearly like shape monomyrian adductor muscle scar, occur near the posterior shell margin.

\section{Remarks:}

This species shows resemblance to species Pinctada margaritifera (LINNE, 1758) in external view, but its distinguished by having tow alates.

\section{Super family: PECTINACEA RAFINIESOUE, 1815 \\ Family: SPONDYLIDAE GRAY, 1826 \\ Genus: Spondylus LINNE, 1758}

Type species: Spondylus gaederopus LINNE, 1758 SD by SCHMDIT, 1818.

Subgenus: Spondylus s. st

Spondylus (Spondylus) gaederopus LINNE, 1758

(Plate1, Fig. 3a, 3b)

SYNONYMY:

1758 Spondylus gaederopus LINNE, ed 10, P. 690; ed. 12, 1767, P.1136. 1968 Spondylus aculaeatus CHEMNITZ in STEININGER PL. 2, Fig. 8a,b. 


\section{Dimensions:}

\begin{tabular}{|c|c|c|}
\hline $\begin{array}{c}\text { Specimen } \\
\text { numberes(n) }\end{array}$ & height & length \\
\hline 1 & 3.6 & 4.6 \\
\hline 2 & 3.8 & 4.5 \\
\hline
\end{tabular}

\section{Description:}

Medium sized shell, averaging about $80 \%$ as height as length $(\mathrm{H}=3.7 \mathrm{Cm}, \mathrm{L}=4.6 \mathrm{~cm}, \mathrm{n}=2)$. Orbicular shell shape and semiequivalent valves with the moderately convex right valve, dorsal margin straight occupied about half of the shell length, umbo small and slightly raised upward, posterior and anterior shell margins are nearly equilateral, converging toward the ventral margin. Shell ornamented by distanced laminated growth lines, crossed by strong numerous radial ribs of an plicae bears type many spines and nodules on the external shell surface, lateral and ventral margins are strongly crenulated. Teeth are of isodont type, two obvious prominent subequal teeth occure at the hingment area, muscle scar monomyrian, oval like shaped, placed at the posterior side and tending to be central in position.

\section{Remarks:}

The present species cannot resemble the subgenus Eltopera with its type species $S$. fortior in (Cox et al., 1969, P.380, FigC99,3) because the latter shows aless inflated shell and more delicate radial ornament.

Subclass: HETERODONTA NEUMAYER, 1884

Order: VENEROIDA H. ADAMS and A. ADAMS, 1856

Super family: LUCINACEA FLEMING, 1828

Family: UNGULINIDAE ADAMS and ADAMS , 1857

Genus: Diplodonta BRONN, 1831

Type species: Venus lupinus BROCCHI, 1814

Subgenus: Diplodonta s. st

Diplodonta (Diplodonta) rotundata ( MONTAGU, 1803)

(Plate2, Fig.2a,2b)

SYNONYMY:

1803 Tellina rotundata MONTAGU, P.71

Dimensions:

\begin{tabular}{|c|c|c|}
\hline $\begin{array}{c}\text { Specimen } \\
\text { numberes(n) }\end{array}$ & height & length \\
\hline 1 & 1.3 & 1.4 \\
\hline 2 & 1.1 & 1.4 \\
\hline 3 & 1.1 & 1.3 \\
\hline
\end{tabular}

\section{Description:}

Small size shell averaging about $85 \%$ as height as length $(\mathrm{H}=1.2 \mathrm{Cm}, \mathrm{L}=1.4 \mathrm{~cm}$, $\mathrm{n}=3$ ), subquadrated to semi circular in outline with equivalent conjecated valves. Dorsal margin curved, umbo Prosogyral moderately large Prosogyral, lateral shell margins are inequilateral and subparallel, curved toward the ventral margin, to give the circular outline to the shell. Shell surfaces are well ornamented by numerous concentric growth lines, teeth heterodont, ainomyrian muscle scars with an obvious anterior scar. 


\title{
Remarks:
}

The present species is slightly similar in their shell outline to the genus phlyctiderma DALL, 1899 in (Cox et al., 1969a, P.517) but it differs in lacking the numerous orders of teeth and the punctuate or reticulate ornament.

\section{Super family: TELLINACEA DE BLAINVILLE, 1814 \\ Family: SEMILIDE STOLITZKA, 1870 \\ Genus: Semele SCHUMACHER, 1817}

Type species: Tellina proficua PULTENY,1799

Semele sinensis ADAMS, 1853

(Plate 2, Fig. 1a, 1b)

SYNONYMY:

1853 Semele sinensis ADAMS, Vol. XXI, P.253.

Dimensions:

\begin{tabular}{|c|c|c|}
\hline $\begin{array}{c}\text { Specimen } \\
\text { numberes(n) }\end{array}$ & height & length \\
\hline 1 & 3.2 & 3.3 \\
\hline 2 & 3.0 & 3.2 \\
\hline 3 & 3.2 & 3.4 \\
\hline 4 & 3.3 & 3.5 \\
\hline 5 & 3.1 & 3.2 \\
\hline
\end{tabular}

\section{Description:}

Medium sized shell, averaging about $96 \%$ as height as length $(\mathrm{H}=3.2 \mathrm{~cm}$, $\mathrm{L}=3.3 \mathrm{~cm}, \mathrm{n}=5$ ), circular in outline, inequivalent conjugated valves, dorsal margin convex (anterior side of dorsal margin slightly lower than posterior side), lateral shell margins converging towards the ventral margin, ornamentation shows concentric growth lines crossed by radials ribs, radiating from the umbo to the ventrally margin, teeth heterodont (hingeiment bears two small cardinal teeth, occur just below the umbo and one more lateral tooth on each side of them), muscle scars sub equal, large and pear shaped, pallial sinus sub rectangular and ascendant, pallial line not confluent.

\section{Remarks:}

The studied species cannot be included in the genus Semelina DALL, 1900 with its type species Amphidesma nuculoides, CONARD in (Cox et al., 1969a, P.637, Fig. E120-9), because the shell outline and diagnostic features related to genus semele rather than to the genus semelian.

\author{
Super family: VENERACEA RAFINSQUE, 1815 \\ Family: VENERIDAE RAFINSQUE, 1815 \\ Subfamily: CIRCINAE DALL, 1896 \\ Genus: Circe SCHUMACHER, 1817 \\ Type species: Circe violacea SCHUMACHER, 1817 \\ Subgenus: Circe s. st \\ Circe (Circe) scripta (LINNE, 1758)
}

(Plate 2, Fig. 4a, 4b) 
SYNONYMY:

1758 Venus scripta LINNE, P.1135

Dimensions:

\begin{tabular}{|c|c|c|}
\hline $\begin{array}{c}\text { Specimen } \\
\text { numberes(n) }\end{array}$ & height & length \\
\hline 1 & 3.4 & 3.6 \\
\hline 2 & 3.4 & 3.7 \\
\hline 3 & 3.5 & 4.0 \\
\hline 4 & 3.7 & 4.1 \\
\hline 5 & 3.3 & 3.8 \\
\hline 6 & 3.6 & 4.1 \\
\hline
\end{tabular}

\section{Description:}

Medium size shell averaging about $90 \%$ as height as length $(\mathrm{H}=3.5 \mathrm{Cm}, \mathrm{L}=3.9 \mathrm{~cm}$, $\mathrm{n}=6$ ), subtriangular to semicircular in outline, equivalent Conjugated valves. Dorsal margin triangular, posterior and anterior sides subprallel converging ventrally. Umbo prosogyral, moderately large and curved upwards, shell surfaces are well ornamented by numerous intercalating concentric growth lines faint brownish colored zigzag lines. Escutcheon narrow, larger than lunula. Teeth are heterodont (right and left valves with three and four cardinal teeth respectively). The large posterior and the small anterior muscle scars are almost elongated and oval in shape respectively. Pallial sinus is very shallow.

\section{Remarks:}

STEININGER, 1968 identified the present species as $C$. rivularis BORN, which is considered to be synonoym with the former. REEVE 1864, established the same identification.

Circe (Circe) intermedia REEVE, 1863

(Plate1, Fig. 2a, 2b)

SYNONYMY:

1863 Circe intermedia REEVE, Vol. 14, Sp26

Dimensions:

\begin{tabular}{|c|c|c|}
\hline $\begin{array}{c}\text { Specimen } \\
\text { numberes(n) }\end{array}$ & height & length \\
\hline 1 & 4.4 & 4.8 \\
\hline 2 & 4.2 & 4.6 \\
\hline 3 & 4.1 & 4.5 \\
\hline
\end{tabular}

\section{Description:}

Medium shell size, averaging about $91 \%$ as height as length $(\mathrm{H}=4.2 \mathrm{Cm}, \mathrm{L}=4.6 \mathrm{~cm}$, $\mathrm{n}=3$ ), subcircular to subtriangular in outlines, Inequilateral dorsal margin is moderately triangular, umbo prosogyral, curved upward towards dorsal margin, ligament area opisthodetic. Posterior and anterior margins are slightly rounded, curved ventrally. Shell is well ornamented by numerous well spaced concentric growth lines crossed by few faint radial ribs. Teeth heterodont with three cardinal teeth on both valves, occure below the umbo and one extra anterior lateral tooth on the right valve. The large posterior and the 
small anterior muscle scars are almost elongated and oval in shape, pallial line is faint and curved.

\section{Remarks:}

Circe intermedia is more likely resembled Circe scripta, but it differs in having the distinct divercating sculpture on the umbonal area.

\section{Subfamily: CHIONINAE FRIZZELL, 1936 \\ Genus: Bassina JUKES BROWNE, 1914}

Type species: Venus pachyphylla JONAS, 1845, OD.

Subgenus: Bassina s. st

Bassina (Bassina) calophylla (PHILIPPI, 1836)

(Plate1, Fig. 1a, 1b)

SYNONYMY:

1836 Venus calophylla PHILIPPI, P.229, PI.8, Fig. 2.

Dimensions:

\begin{tabular}{|c|c|c|}
\hline $\begin{array}{c}\text { Specimen } \\
\text { numberes(n) }\end{array}$ & height & length \\
\hline 1 & 1.8 & 2.0 \\
\hline 2 & 1.9 & 2.1 \\
\hline 3 & 1.6 & 1.8 \\
\hline 4 & 1.7 & 1.9 \\
\hline
\end{tabular}

\section{Description:}

Small sized shell, averaging about $90 \%$ as height as length $(\mathrm{H}=1.8 \mathrm{Cm}, \mathrm{L}=2.0 \mathrm{~cm}$, $\mathrm{n}=4$ ), ovally triangular in outline, equivalent conjugated valves, dorsal margin convex, posterior margin strongly curved and pointed than anterior margin, ventral margin subrounded, umbo prosogyral, umbonal area in flated, escutcheon long, shell surfaces are well ornamented by numerous widely spaced concentric growth lamina making an obvious crenulations with the shell outline, teeth heterodont (with only three cardinal teeth on each valve), muscle scars anisomyrin with pear like shaped anterior muscle scar and semiquadrate posterior scar, pallial sinus shallow and pointed.

\section{Remarks:}

This species is distinguished by sub triangular to ovally equilateral shell shape and their concentric growth lamina ornaments.

\section{REFERENCES}

Campbell, A.C., 1982. The Hamlyn Guide to the Flora and Fauna of the Mediterranean Sea., Hamlyn Publishing Group Limited, London U.K., 320p.

Cox, L.R.; Newell, N.D.; Branson, C.C.; Raymond Casey; Andre Chavan, Coogan, A. H.; Colette Dechaseaux, Fleming, C.A.; Fritz Haas; Hertlein, L. G.; Myra Keen, A.; Aurele LaRocque; McAlester, A. L.; Perkings, B. F.; Puri, H. S.; Smith, L.A.; Soot-Ryen, T.; Stenzel, H.B.; Turner, R.D. and John Weir, 1969. Systematic Descriptions in R.C. Moore, ed., Treatise on Invertebrate Paleontology, Pt. N, Vol. 1 (of 3), PP. 225-489, Mollusca 6. Bivalvia, the Univ. of Kansas and the Geological Society of America, Inc., Lawrence, Kansas. 
Cox, L.R.; Newell, N.D.; Boyd, D.W.; Branson, C.C.; Raymond Casey; Andre Chavan; Coogan, A.H.; Colette Dechaseaux; Fleming, C.A.; Fritz Haas; Hertlein, L.G.; Kauffman, E.G.; Myra Keen, A.; Aurele LaRocque; McAlester, A.L.; Moore, R. C.; Nuttall, C.P.; Perkings, B.F.; Puri, H.S.; Smith, L.A.; Soot-Ryen, T.; Stenzel, H.B.; Trueman, E.R.; Turner, R.D. and John Weir, 1969a. Systematic Classifications., In R.C. Moore, ed., Treatise on Invertebrate Paleontology, Pt. N, Vol. 2 (of 3), pp. 491-952, Mollusca 6. Bivalvia, the Geological Society of America, Inc., and the Universty. of Kansas, Lawrence, Kansas.

Elewi, A.H. and Safawee, N.M., 1987. On the Distribution of Recent Foraminifera From Southern Iraq. Marine Mesopotamica, 2(1), pp. 41-65.

Elewi, A.H. and Safawee, N.M., 1989. On the Distribution of Recent Foraminifera From Northwestern Arabian Gulf. Marine Mesopotamica, 2(1), pp. 243-279.

Mondadori, A., 1982. The Macdonald Eencyclopedia of Shells, Macdonald and Co (publishers)Ltd, London U.K., 512p.

Stenzel, H.B., 1971. Treatise on Invertebrate Paleontology, Pt. N, Vol. 3

(of 3), PP. 953-1224, Mollusca 6. Bivalvia, the Geological Society of America, Inc., and the Universty. of Kansas, Lawrence, Kansas.

Steininger, F., 1968. Special Investigations Report Marine Molluscs In Fuchs et al., ed., Explanatory Text to the Synobtic Geologic Map of Kuwait, pp. 37-49, 4 pl. Geological Survey of Viena, Austria.

Vrsaljlo, D.; Pavelic, D.; Miknic, M.; Brkic, M.; Kovacic, M,; Hecimovic, Tadesse, V.H.; Avanic, R. and Kurtanjek, N., 2006. Middle Miocene (Upper Badenian / Sarmatian) Palaeoecology and Evolution of the environments in the area of Medvednica Mt. (Uppercroatia), Geol. Croatia Vol. 59, No. 1, pp. 51-63. 


\section{PLATE 1}

- Figs. 1a and 1b: Bassina (Bassina) calophylla (PHILIPPI, 1836), illustrating the internal and the external features of left and right valves respectively, Hajam Island, $\mathrm{X}=2.9$

- Figs. 2a and 2b: Circe (Circe) intermedia REEVE, 1863, Showing the internal and the external features of right and left valves respectively, Hajam Island, $\mathrm{X}=1.2$

- Figs. 3a and 3b: Spondylus (Spondylus) gaederopus LINNE, 1758, revealing the internal and the external features of left and right valves respectively, Hajam Island, $\mathrm{X}=1.4$

- Figs. 4a and 4b: Pinctada radiata LEACH, 1814, demonstrating the internal and the external features of right and left valves respectively, Hajam Island, $\mathrm{X}=0.9$

\section{PLATE 2}

- Figs. 1a and 1b: Semele sinensis A. ADAMS, 1853, showing the internal and the external features of right and left valves respectively, Hajam Island, $\mathrm{X}=1.6$

- Figs. 2a and 2b: Diplodonta (Diplodonta) rotundata ( MONTAGU, 1803), demonstrating the internal and the external features of right and left valves respectively, Hajam Island, $\mathrm{X}=3.8$

- Figs. 3a and 3b: Barbatia helblingii (BRUGIERE,1789) revealing the internal and the external features of right and left valves respectively, Hajam Island, $\mathrm{X}=4.3$

- Figs. 4a and 4b: Circe (Circe) scripta LINNE, 1758 illustrating the internal and the external features of right and left valves respectively, Hajam Island, $\mathrm{X}=1.3$

- Fig. 5a: Pinctada margaritifera (LINNE, 1758) demonstrating the external features of left valve, Hajam Island, $\mathrm{X}=0.8$ 


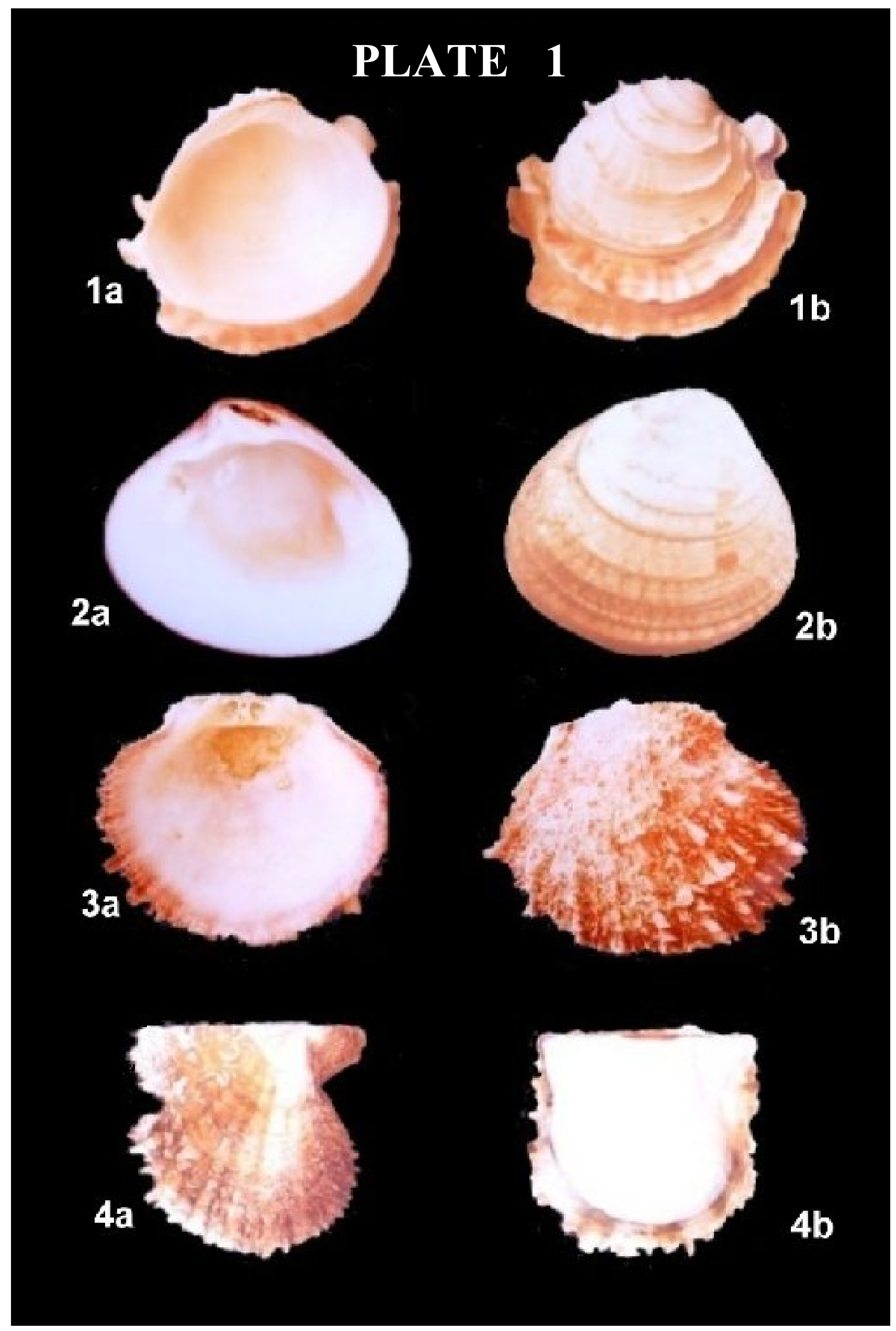


(59) Iraqi Journal of Earth Sciences, Vol. 8- No. 2- November- 2008

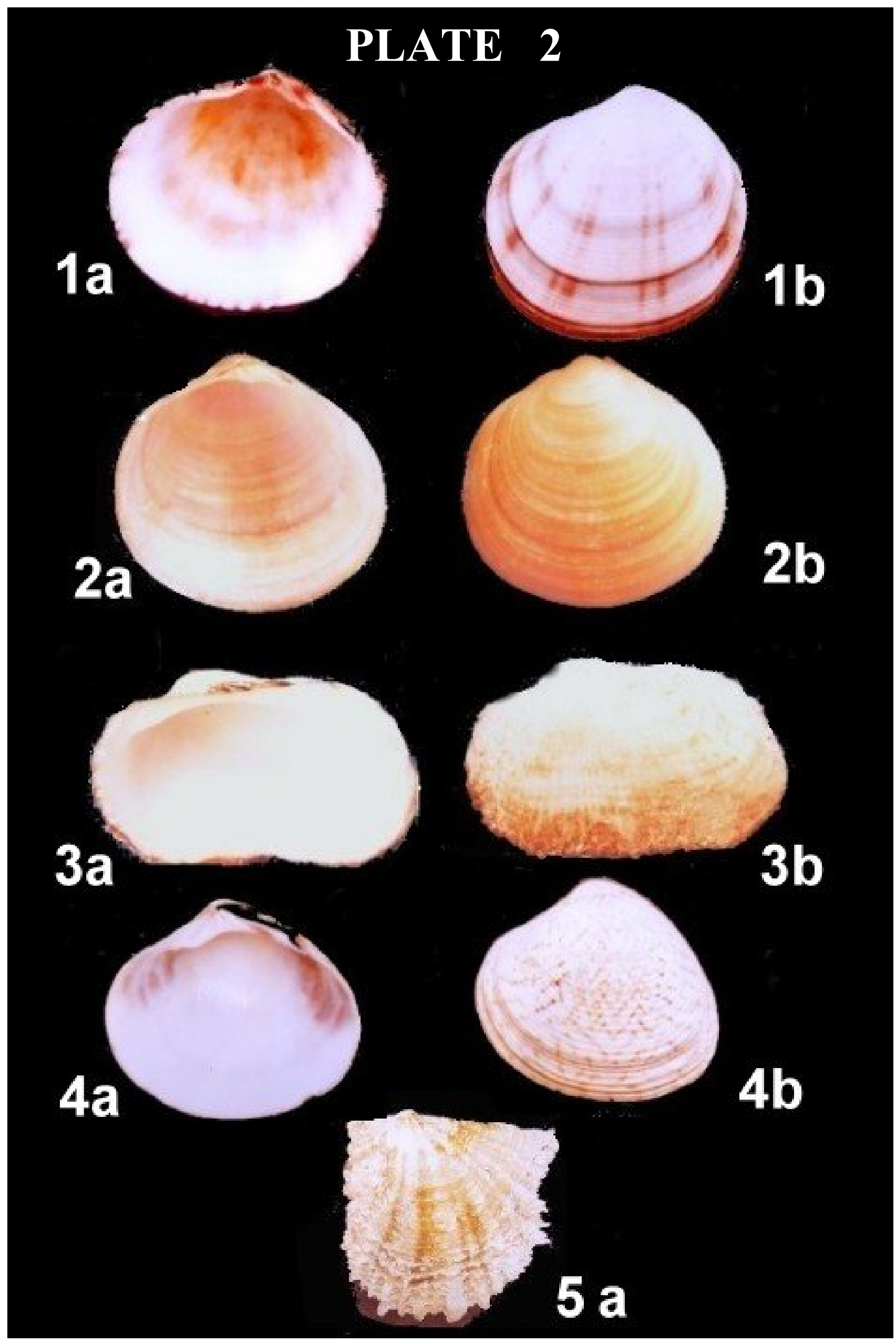

